\title{
A Profile of the Structure and Impact of Nursing Management in Canadian Hospitals
}

\author{
Heather K. Spence Laschinger, Carol A. Wong, Judith Ritchie, Danielle D'Amour, Leslie Vincent, Piotr Wilk, \\ Marjorie Armstrong Stassen, Sue Matthews, Marcy Saxe-Braithwaite, Doris Grinspun, Judith Shamian, Amy McCutcheon, \\ Michael Kerr, Sandra Macdonald-Rencz, Barbara Oke, Donna Denney, Jerry White and Joan Almost
}

\begin{abstract}
The purpose of this study was to describe the profile of nursing leadership structures in Canada and to assess relationships among structures, processes and outcomes pertaining to nurse leaders' work. Data were collected from nurse leaders in 28 academic health centres and 38 community hospitals in 10 Canadian provinces $(n=1,164)$. The results of this study revealed that the current contingent of nursing leaders in Canada see themselves as an empowered and influential group within their organizations. Despite very large spans of control, nurse leaders at all levels were positive about their work life and confident in their ability to provide effective leadership on nursing affairs within their organizations. Structural and process factors significantly affected nurse manager outcomes at all levels. Senior nurse leaders' work-life factors had a significant effect on middle and first-line managers' perceptions of patient care quality in the organization. Nurse leaders averaged 49 years of age highlighting the need for succession planning.
\end{abstract}

\section{Background}

Nursing leadership positions in Canada have decreased by $6,849(29 \%)$ as a result of hospital restructuring in the 1990 s (Canadian Institute for Health Information 2001, 2002, 2003, 2004; Canadian Nursing Advisory Committee [CNAC] 2002). Those nurse leaders remaining have greatly expanded areas of responsibility and spans of control (Doran et al. 2004), reduced visibility and less availability for mentor- ing and support (CNAC 2002; Grinspun 2000; Norrish and Rundall 2001). Several documents (Baumann et al. 2001; Broughton 2001; CNAC 2002; Ferguson-Pare et al. 2002; Mass et al. 2006) have emphasized the importance of strong nursing leadership in hospital settings to ensure that nursing input on patient care process issues is built into the system.

The nursing leadership team plays a key role in providing the direction and infrastructure to ensure that nurses are empowered to practise professionally and thus deliver highquality care (Clifford 1998). This involves not only increasing the numbers of nursing leadership positions, but also ensuring that nurse managers have reasonable spans of control that allow them sufficient contact with nurses in the setting and time to complete their duties (CNAC 2002; Ontario Ministry of Health Report of the Nursing Task Force 1999). There is concern about the shortage of nurses interested in management and leadership positions, highlighting the need for systematic succession planning, not only to encourage nurses to move into these roles but to provide the necessary training to develop competencies for leadership.

Healthcare restructuring in the 1990s resulted in dramatic changes in nursing leadership roles. While there is much speculation about the impact of these changes in nursing leadership, surprisingly little is known about how nursing leadership roles in Canada are currently structured within the larger healthcare delivery system. The purpose of this study was to describe the profile of nursing leadership struc- 
Figure 1. Conceptual model

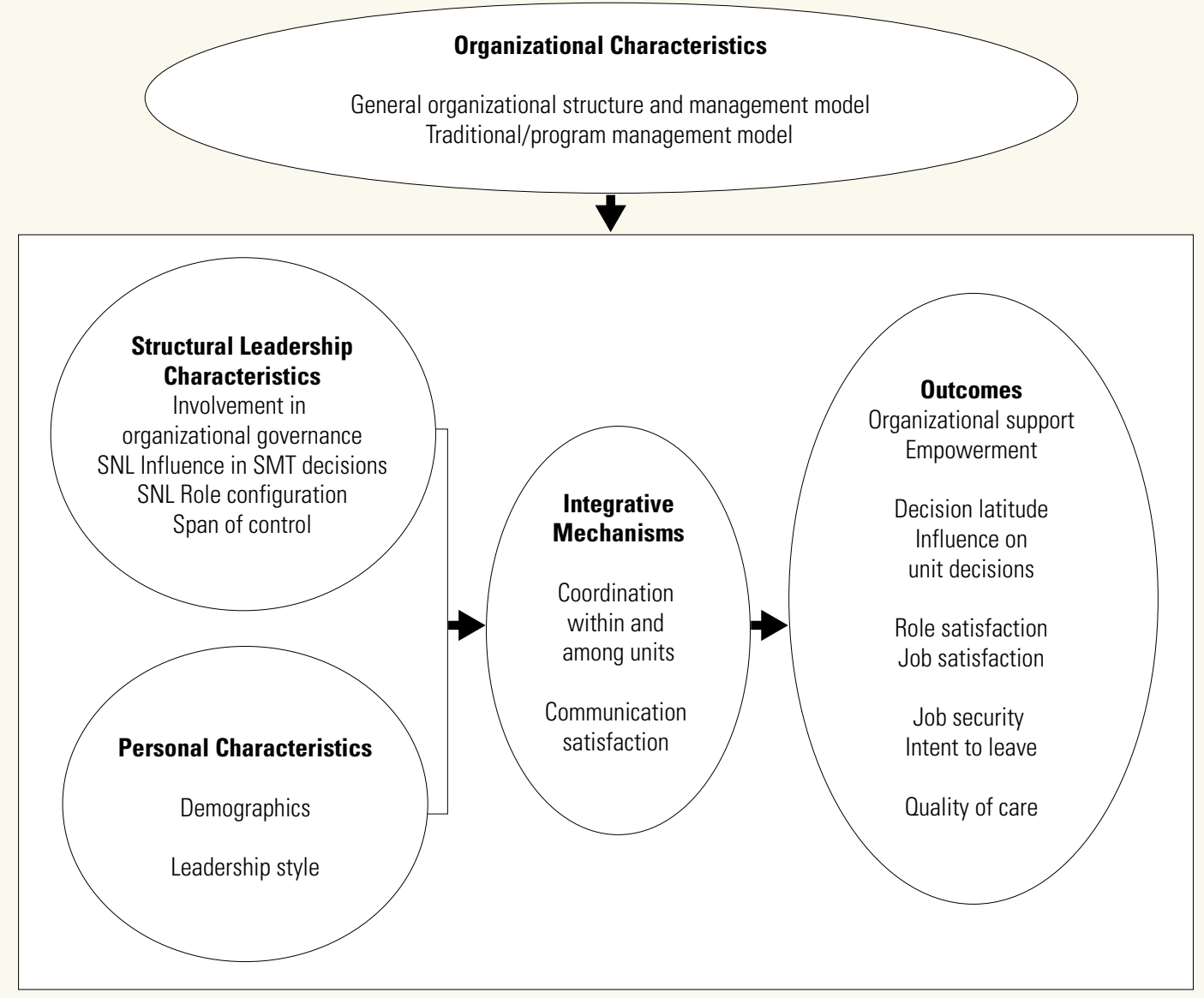

SMT = senior management team.

longer had operational line responsibility for nursing services (Broughton2001; Clifford 1998; Gelinas and Manthey 1997). Middle and firstline leadership roles were also expanded to include responsibility for other disciplines as well as nursing. Although some believe that these changes provide nurse leaders with an opportunity to play a greater role in decision-making within the new multidisciplinary program structures, others disagree. They argue that these changes diminish communication links between

tures in Canada and to assess relationships among personal and structural factors, organizational processes and outcomes pertaining to nurse leaders' work. The study focused primarily on nursing leadership in acute care settings since the majority of nurses practice in these settings.

New governance structures, systems of care and organizational models have radically changed nursing leadership structures (Baumann et al. 2001; Gelinas and Manthey 1997; Grinspun 2000; Havens 1998, 2001). In the 1990s, program management structures, in which multidisciplinary teams provide care organized around specific patient populations, replaced traditional departmental structures (Leatt et al. 1994; Smith et al. 2006). A consequence of the program management model was the loss of a senior executive with sole responsibility for nursing affairs in the organization.

All nursing leadership roles changed dramatically within this system. Many chief nursing executives took on added responsibilities beyond nursing services, while others no senior nurse leaders (SNLs) and other nursing personnel at lower levels of the organization, and deprive nurses of disciplinary leadership representation at the policy making level in the organization (Clifford 1998; CNAC 2002; Grinspun 2000). As a result, nursing work organization suffers, threatening the quality of patient care (Clifford 1998).

\section{Conceptual Model}

We have developed a conceptual model to guide this study based on a review of the nursing, health services and organizational theory literature (Figure 1). Within this framework, structural characteristics of SNLs, such as role configuration, scope and intensity of decisional involvement in the senior management team (SMT) and span of control, influence their perceived role effectiveness, influence in the organization and job satisfaction. The scope and intensity of SNLs' involvement in SMT strategic decision-making has been shown to increase their perceptions of influence in 
Despite very large spans of control, nurse leaders at all levels were positive about their work life and confident in their ability to provide effective leadership on nursing affairs within their organizations... somewhat surprising in light of anecdotal reports that suggest high levels of stress and heavy workloads.

the organization (Ashmos et al. 1998; Banaszak-Holl et al. 1999). Large spans of control hinder organizational performance where high levels of communication are necessary for effective accomplishment of work (Gittell 2001). Doran et al. (2004) found that large spans of control reduce the effect of positive leadership styles on staff and patient satisfaction. These structural characteristics of SNLs in combination with individual characteristics, such as the use of transformational leadership behaviours, influence whether or not integrating mechanisms are in place among levels in the organization to support professional nursing practice.

Integrative mechanisms, such as coordination within and across units and strong communication mechanisms, promote effective accomplishment of work and result in greater satisfaction and organizational commitment for both senior leaders and their subordinates (Relf 1995; Rose and Reynolds 1995; Webb et al. 1996). The quality of manager-subordinate communication is strongly related to subordinate job satisfaction (Pincus 1986; Prescott and Bowen 1987). Supportive leadership styles, in particular transformational styles, also affect the quality of communication and, ultimately, subordinate satisfaction, commitment and productivity (Eisenberger et al. 1990; Gresham and Brown 1997; Irvine and Evans 1995; Loke 2001; Miller and Miller 1997). Similar patterns of relationships among structural factors and outcomes would be expected at other levels of management. We also hypothesized that there would be cross-level effects, that is, working conditions at one level of management would have an impact on those at lower levels of the organization.

Finally, organizational factors, such as organizational structure and the management model (program management, departmental management), can have an impact on any of the proposed relationships in the model. For instance, program management structures are associated with positive outcomes such as increased interdisciplinary teamwork and decisional involvement, flexibility and fewer adverse events for patients (Miller and Miller 1997). However, negative outcomes, such as sense of isolation from peers, increased workload and job dissatisfaction, have also been identified (Michalski et al. 1999).

\section{Methods}

\section{Sample and Data Collection Procedures}

Data were collected from nurse leaders in 28 academic health centres and 38 community hospitals in 10 Canadian provinces. Community hospitals with $>100$ beds within each academic health centre geographical region were purposively selected. Sixty-six SNLs, 384 middle managers, 1,462 first-line managers, 40 professional practice leaders and 66 chief executive officers (CEOs) were surveyed by mail (Appendix 1, http://www.longwoods.com/product. php? productid $=19596$ ). Of the original 2,018 surveys, 1,164 surveys were returned, for an overall response rate of 58\% (Appendix 2, http://www.longwoods.com/product. php?productid=19596).

\section{Instruments}

Several self-report standardized measures were used to measure each of the variables in the conceptual model (Appendix 3, http://www.longwoods.com/product. php? productid=19596). The research team adapted existing questionnaires to obtain descriptive data about structural aspects of nurse leader roles. Open-ended questions were used to identify role changes, barriers and facilitators to role effectiveness and information on the organization of nursing services in the various settings.

\section{Data Analyses}

Quantitative survey data were analyzed using SPSS 14.0 for Windows (SPSS Inc. 2005). Descriptive statistics were analyzed by hospital type (academic health centre and community hospital) and level of management. A series of correlation analyses were used to examine relationships among structural and personal characteristics, integrative mechanisms and outcomes within each level of management. Finally, HLM 6 (Raudenbush et al. 2005) was used to test cross-level effects among levels of management.

\section{Results \\ Descriptive Results \\ Demographics}

Demographics of the sample are illustrated in Table 1. A notable finding was the high average age (47-51 years) of nurse leaders at all levels, suggesting the urgent need for succession planning to ensure the future of nursing leadership. Furthermore, there was little age gradient across levels of nursing management. These results are similar to those of other studies recently conducted with senior nurse managers (Mass et al. 2006; O’Brien-Pallas et al. 2004). When grouped into age categories, the results show that there were few SNLs under the age of 45 years. A similar age distribution was evident in the middle and first-line manager groups. Most 
Table 1. Demographics by management level

\begin{tabular}{|c|c|c|c|c|c|c|}
\hline & \multicolumn{2}{|c|}{ SNL } & \multicolumn{2}{|c|}{ MM } & \multicolumn{2}{|c|}{ FLM } \\
\hline & Mean & SD & Mean & SD & Mean & SD \\
\hline Age (yr) & 50.4 & 4.8 & 48.2 & 6.4 & 47.1 & 7.1 \\
\hline Management experience (yr) & 20.8 & 6.7 & 15.1 & 7.7 & 11.3 & 8.4 \\
\hline \multirow[t]{3}{*}{ Years in role } & 3.7 & 3.3 & 4.3 & 4.5 & 6.6 & 6.5 \\
\hline & \multicolumn{2}{|c|}{ SNL } & \multicolumn{2}{|c|}{ МM } & \multicolumn{2}{|c|}{ FLM } \\
\hline & $n$ & $\%$ & $n$ & $\%$ & $n$ & $\%$ \\
\hline $\begin{array}{l}\text { Gender } \\
\text { Male } \\
\text { Female }\end{array}$ & $\begin{array}{c}0 \\
63\end{array}$ & $\begin{array}{c}0 \\
100\end{array}$ & $\begin{array}{c}13 \\
216\end{array}$ & $\begin{array}{c}5.6 \\
93.5\end{array}$ & $\begin{array}{c}40 \\
740\end{array}$ & $\begin{array}{c}5.1 \\
94.9\end{array}$ \\
\hline $\begin{array}{l}\text { Highest level of nursing education } \\
\text { Diploma } \\
\text { Baccalaureate } \\
\text { Master's degree } \\
\text { PhD }\end{array}$ & $\begin{array}{c}2 \\
19 \\
34 \\
4\end{array}$ & $\begin{array}{c}3.4 \\
32.2 \\
57.6 \\
6.8\end{array}$ & $\begin{array}{c}13 \\
112 \\
84 \\
3\end{array}$ & $\begin{array}{c}6.1 \\
52.8 \\
39.6 \\
1.4\end{array}$ & $\begin{array}{c}86 \\
536 \\
128 \\
4\end{array}$ & $\begin{array}{c}11.4 \\
71.1 \\
17.0 \\
0.5\end{array}$ \\
\hline
\end{tabular}

FLM = first-line manager; $\mathrm{MM}=$ middle manager; $\mathrm{SNL}$ = senior nurse leader

$36 \%$ of first-line managers had less than five (see Table 2). Interestingly, almost $40 \%$ of managers with less than five years of experience were 45 55 years of age, suggesting that nurses under 40 are not assuming manager roles.

\section{Structural Variables}

Overall, managers reported very large spans of control, although there was considerable variation within each management level (Table 3). SNLs averaged 12 direct reports (range 247). Middle managers also averaged 12 direct reports (range 1-40). Firstline managers averaged 71 direct reports (range 5-264). Twenty percent reported $>100$ direct reports. These results are somewhat similar to those from a national study by O'BrienPallas et al. (2004) and a study of first-line managers by Doran et al. (2004) (mean $=77$, range $=36-$ 151).

Nursing leadership structures differed in the configuration of SNLs' roles, the presence or absence of a distinct nursing department and the number of levels of nursing management. Two major role configurations were identified: (1) those with line authority and (2) those without line authority. The majority of SNLs (84\%) had operational/line authority for clinical programs $(n=$

nurse leaders were between 46 and 55 years of age, and there were only $2.2 \%$ of first-line and $6.3 \%$ of middle managers in the $26-35$ age group (Table 2).

Overall, current nurse leaders were very experienced individuals with $11-21$ years of management experience. Over $80 \%$ of SNLs had at least 15 years of management experience, and all had at least five years. In contrast, $45 \%$ of middle managers and 30\% of first-line managers had over 15 years' experience, while only $10 \%$ of middle managers and
55), similar to the findings of O'Brien-Pallas et al. (2004). Most (87\%) reported directly to the CEO and had chief nursing officer in their titles (67\%). Reporting directly to the CEO was twice as likely to occur in community hospitals as in academic health centres (67\% versus 33\%). A few SNLs, primarily in the West, reported to a senior vice-president or executive director rather than the CEO. The majority of SNLs with chief nursing officer titles were employed in Ontario (47\%) and Quebec (28\%). 
Sixteen percent of SNLs $(n=11)$ did not have operational/line authority for clinical programs, but all had line responsibility for professional practice personnel. Most (73\%) reported directly to the CEO. All had CNO in their titles, and all but one reported they were members of the SMT.

Traditional distinct nursing departments were rare (20\%); these were found mostly in community hospitals $(77 \%)$ and in the province of Quebec (61\%). Program management was the most common management structure in hospitals without a distinct nursing department. SNLs reported that the chief nursing officer, professional practice leader/director positions and/or nursing professional practice committees had assumed responsibility for nursing practice issues in the absence of a traditional nursing department structure. Nursing practice councils and regular meetings with all levels of managers were described as important for ensuring organizational alignment on nursing and patient care issues. Professional practice leader roles were more prevalent (68\%) in academic health centres. Resources for nursing education and development were prevalent in both academic health centres and community hospitals, but resource support for research was limited to academic health centers.

Organizations reported between two and five levels of nursing management. The majority of organizations (65.2\%) reported three levels of management: first-line, middle and senior nursing management. Fifty percent of academic health centres had two senior levels of nursing management in their organizational structures. Two large regional health authorities reported five or six levels of management, with two levels of first-line management, one or two levels of middle management and two levels of senior management.

\section{Work-Life Characteristics}

Nurse leaders at all levels of management were remarkably positive about their work environments (Table 4). All levels of management reported moderate to high levels of transformational leadership behaviour used by SNLs and themselves, satisfaction with the level of communication with their supervisors, perceived organizational support (POS), empowerment, support for professional nursing practice, influence on unit decision-making, job and role satisfaction, job security and patient care quality in their organizations (see Table 4). Overall, nurse leaders rated these characteristics higher than did those in leadership roles below them, that is, SNLs' ratings were higher than those of middle managers, and middle managers' ratings were higher than those of firstline managers.

SNLs felt that they were integral members of the SMT, reporting high levels of involvement and influence in senior management decisions. SNLs had a title and salary comparable to those of other executives in both traditional (distinct professional departments) and program management structures. Overall, SNLs felt that senior management decisions were compatible with existing constraints, timed to gain maximum benefit, based on an optimal amount of information, appropriately balanced between risks and rewards and made with an understanding of the basis and implications of the decision by the senior team.

\section{Impact of Structural Variables}

SNLs and middle managers working within program management structures felt more support from the organization (POS), job security and greater support for professional nursing practice than did those in traditional structures. In comparison, nurse leaders working in organizations with traditional departmental structures were more empowered, reported with greater influence on unit decisions and were more confident in patients' ability to manage their care after discharge.

SNLs with operational/line authority were viewed by all levels of management as having higher status in the organization and greater involvement in senior management activities than those with staff authority. SNLs with line authority reported higher status (title and salary) within their organization, greater involvement in SMT decisions and earlier involvement in the process than did those in staff authority positions. They also felt greater support from their organization (POS) and were more satisfied with the quality of SMT decisions. Middle managers and first-line managers in their organizations also reported more support for a professional practice environment, although the difference was not significant for middle managers (Appendix 4, http://www. longwoods.com/product. php? productid=19596) . 
Table 4. Means and standard deviations of major study variables

\begin{tabular}{|c|c|c|c|c|c|c|c|}
\hline & \multirow{2}{*}{$\begin{array}{c}\text { Possible Score } \\
\text { Range }\end{array}$} & \multicolumn{2}{|c|}{ SNL } & \multicolumn{2}{|c|}{ MM } & \multicolumn{2}{|c|}{ FLM } \\
\hline & & Mean & SD & Mean & SD & Mean & SD \\
\hline \multicolumn{8}{|l|}{ SNL role in senior team } \\
\hline $\begin{array}{l}\text { Scope of decisional involvement } \\
\text { Decision influence } \\
\text { Quality of management decisions }\end{array}$ & $\begin{array}{l}0-5 \\
0-5 \\
0-5\end{array}$ & $\begin{array}{l}4.14 \\
4.22 \\
3.79\end{array}$ & $\begin{array}{l}0.94 \\
0.77 \\
0.68\end{array}$ & $\begin{array}{l}- \\
- \\
-\end{array}$ & $\begin{array}{l}- \\
- \\
-\end{array}$ & $\begin{array}{l}- \\
- \\
-\end{array}$ & $\begin{array}{l}- \\
- \\
-\end{array}$ \\
\hline \multicolumn{8}{|l|}{ Structural variables } \\
\hline Self-rated leadership style & $1-10$ & 8.53 & 0.70 & 8.26 & 0.78 & 8.07 & 0.90 \\
\hline Other-rated SNL leadership style & - & - & - & 7.83 & 1.46 & 7.80 & 1.50 \\
\hline Perceived organizational support & $1-7$ & 5.00 & 0.89 & 4.16 & 1.11 & 3.77 & 1.19 \\
\hline Level of job security & $1-4$ & 3.22 & 0.64 & 3.21 & 0.60 & 3.22 & 0.61 \\
\hline \multicolumn{8}{|l|}{ Integrative mechanisms } \\
\hline Coordination within units & $1-5$ & 3.77 & 0.48 & 3.93 & 0.49 & 4.00 & 0.50 \\
\hline Coordination among units & $1-5$ & 3.29 & 0.49 & 3.50 & 0.61 & 3.60 & 0.63 \\
\hline Communication satisfaction & $1-7$ & 6.27 & 0.98 & 5.94 & 1.25 & 5.86 & 1.23 \\
\hline \multicolumn{8}{|l|}{ Work-life variables } \\
\hline Total empowerment & $6-30$ & 24.08 & 2.91 & 21.71 & 2.89 & 20.55 & 3.16 \\
\hline Support for professional practice & $1-4$ & 2.98 & 0.44 & 3.05 & 0.43 & 3.03 & 0.48 \\
\hline Role satisfaction & $1-5$ & 4.25 & 0.85 & 3.83 & 0.86 & 3.53 & 0.86 \\
\hline Job satisfaction & $1-5$ & 4.30 & 0.68 & 3.91 & 0.84 & 3.54 & 0.91 \\
\hline Influence in unit policy decisions & $1-5$ & - & - & 3.93 & 0.61 & 3.71 & 0.77 \\
\hline Decision latitude & $1-5$ & - & - & 3.82 & 0.75 & 3.70 & 0.80 \\
\hline \multicolumn{8}{|l|}{ Quality of care } \\
\hline Quality of care in hospital & $1-4$ & - & - & 3.34 & 0.55 & 3.47 & 0.58 \\
\hline Patients can manage at discharge & $1-4$ & 2.62 & 0.52 & 2.88 & 0.64 & 3.03 & 0.66 \\
\hline
\end{tabular}

FLM = first-line manager; $\mathrm{MM}=$ middle manager; $\mathrm{SNL}$ = senior nurse leader .

SNLs who reported greater influence in senior management decisions and higher quality of senior management decisions were more likely to feel empowered, feel valued by the organization (POS) and report positive changes in patient care quality in their organization over the past year. SNL ratings of senior management decision quality were also related to greater support for professional nursing practice, role satisfaction and satisfaction with communication with their supervisors (Appendix 5, http://www. longwoods.com/product.php?productid=19596). SNLs' perceptions of a comparable salary and title to similar roles within their organization were associated with their levels of POS, role satisfaction, influence in senior management decisions, perceived quality of senior management decisions and support for professional practice in their hospitals (see Appendix 5, http://www.longwoods.com/product.php? productid=19596).

SNLs with higher numbers of direct reports reported a greater influence on SMT decisions and were more likely to report a positive change in patient care quality over the past year. Middle managers with higher spans of control reported lower organizational support (POS), less decision latitude and a greater intent to leave, and they rated their SNLs lower in transformational leadership behaviours. First-line manag- 
ers with a higher number of direct reports reported greater influence on unit decision-making and greater decision latitude but lower levels of coordination within and among units and lower confidence in patients' ability to manage at discharge (Appendix 6, http://www.longwoods.com/product. php?productid=19596).

SNLs' use of transformational leadership behaviours were important to lower-level managers. When middle and firstline managers perceived their SNL to be a transformational leader, they reported higher levels of empowerment, POS, communication satisfaction, decision latitude and influence, support for professional practice and job and role satisfaction, and lower turnover intentions. They also reported greater confidence in patients' ability to manage care at discharge (Appendix 7, http://www.longwoods.com/product. php?productid=19596).

Finally, nurse leaders' job satisfaction was strongly related to a variety of work-life variables, such as organizational support (POS), empowerment, satisfaction with communication with their supervisors, support for professional practice and role satisfaction. High-quality senior management decisions were particularly important for SNLs' job satisfaction. POS and structural empowerment were most strongly related to job satisfaction across all levels of management. Job satisfaction was significantly related to the intent to leave, particularly for SNLs (Appendix 8).

\section{Cross-Level Effects}

Several cross-level effects were observed in this study. SNLs' work-life factors had a significant effect on middle and firstline managers' perceptions of patient care quality in the organization. Middle managers were more likely to report great quality of care when SNLs rated SMT decisions highly (.20), were satisfied with their role (.12) and reported strong support for professional practice (.234). They also were more likely to report greater support for professional practice (.561) and greater decision latitude (.352) if their SNL was in a staff authority role. First-line managers were more likely to report higher quality of patient care when their SNL reported highquality SMT decisions (.142), influence on SMT decisions (.083) and high support for professional practice (.15) and used transformational leadership behaviours (.068).

Similarly, middle manager work-life factors had a significant impact on first-line managers' work life. Higher middle manager POSs were significantly related to greater first-line manager POSs (.004), empowerment (.016), job (.005) and role satisfaction (.006) and ratings of patient care quality (.134). Middle manager self-rated transformational leadership style was significantly related to higher first-line manager perceptions of a supportive professional practice environment in the organization (.075) and higher patient care quality (.102). First-line managers' job satisfaction was higher when their middle manager was satisfied with the level of communication with their supervisor (.166).

\section{Discussion}

The results of this study revealed that the current cadre of nursing leaders in Canada see themselves as an empowered and influential group within their organizations. Nurse leaders at all levels were positive about their work life and confident in their ability to provide effective leadership on nursing affairs within their organizations. These results are somewhat surprising in light of anecdotal reports in the literature that suggest high levels of stress and heavy workloads.

Contrary to the fears of many that the loss of a distinct department of nursing would have a negative impact on nursing in the organization, SNLs in this study felt that they were an integral member of the SMT and influential in organizational decision-making. Furthermore, the extent of their involvement in SMT decision-making was related to lower-level managers' perceptions of patient care quality in their organizations. Program management structures did not have the negative effect proposed by critics. This suggests that, at least in current nursing leadership structures, nursing issues are being adequately addressed by nursing leaders in the highest levels of organizational decision-making. This finding may be due to the fact that the incumbents in current nursing leadership roles are a very experienced group who are familiar with organizational dynamics and are therefore knowledgeable about how to navigate the system despite dramatic changes in organizational structure. While these experienced nurse leaders may be able to handle the demands of their greatly expanded roles, it is not clear how easily less experienced leaders will be able to transition to these roles.

The average age of nurse leaders at all levels was high (47-51 years), suggesting the immediate and urgent need for succession planning to ensure the future of nursing leadership. Several national reports (CNAC 2002; Ferguson-Pare et al. 2002; Mass et al. 2006), including a Canadian Health Services Research Foundation (2006) report outlining the priorities for nursing leadership, have emphasized the movement between roles (clinician to manager) and encouraged succession planning for nurse leaders. Much needs to be done to attract nurses to leadership positions.

Overall, managers reported very large spans of control with considerable variation in each management level. Our findings showed that higher numbers of direct reports can result in both negative and positive outcomes. At the SNL level, higher numbers of direct reports predominantly had a negative impact, while at the middle and first-line manager levels, higher numbers of direct reports resulted in greater job dissatisfaction but more influence in staff and policy 
decisions. The majority of participants stressed the need to redefine the span of control beyond the number of direct reports. Others suggested that the number of units, programs and sites, the level of clinical and administrative resources available and the level of external demand and changing realities are important factors that should be considered in any examination of span of control.

The results of this study highlight the importance of a positive organizational environment at all levels of the organization. Transformational leadership behaviours, POS and quality communication had an impact on the satisfaction and quality of care for each subsequent level of manager. Working relationships between all levels of management are critical to both role effectiveness and satisfaction. Interestingly, nurse leaders rated their work environment higher than each subsequent role below them (i.e., SNLs' ratings were greater than those of middle managers, whose ratings were greater than those of first-line managers). In addition, perceptions about the relationship to the SMT differed according to management position: senior nurse executives felt they were able to influence budgetary allocations, participate in decisions and act at the board level. However, middle managers did not feel the same degree of integration, and first-line managers felt even less.

\section{Improving recruitment initiatives to target the younger generation of nurses, who place higher value on work-life balance and are less likely to apply for management positions, is critical to the future of nursing leadership.}

\section{Implications}

Policy makers and organizational leaders can use the results of this study to create evidence-based plans and decisions in the recruitment and retention of individuals in nursing leadership roles. Improving recruitment initiatives to target the younger generation of nurses, who place higher value on work-life balance and are less likely to apply for management positions, is critical to the future of nursing leadership. Organizations should reassess their current compensation levels and consider changing these levels to be fair and reflective of managers' additional responsibilities and workload Definitive succession planning strategies are priorities for all healthcare organizations. Actively promoting leadership roles, as well as defining and creating a better understanding of the roles and responsibilities at each level of management, will provide nurses with the opportunities to know what to expect as managers. Knowledge about the differences in leadership structures and attributes at different levels of the organiza- tional hierarchy can better prepare nurse leaders to make these transitions.

In addition, a systemic, deliberate, multi-level approach to career development should be created with educational support to teach standardized leadership training (RNAO 2006). Currently, there is little time for leaders to develop personal goals in areas such as research or education and to branch outside their own networks to gain empowerment in a larger sense. All levels of management should have access to financial resources and flexibility to pursue educational and mentorship opportunities that allow for the long-term development of professional practice. Knowledge gained from this study can be incorporated into leadership education and training programs to prepare future nursing leaders for the complexities of healthcare leadership.

Policy makers and decision-makers can use the results of this study to assist with the development of an online survey collecting information annually about the span of control/responsibility and best practices related to supports for managers (e.g., innovative ways that managers cope with large span of control). Organizations and nurse leaders should ensure a manageable span of control that allows managers to have time to support staff nurses and be available for mentoring/support and development. Support should be provided for managers in carrying out both clinical and administrative aspects of the role - both from administrative personnel and from upper management. Similar recommendations were made in the CNAC (2002) report.

This study provides important information for decisionmakers on the essential factors that influence nursing leadership role effectiveness and positive work environments for nurse leaders. Barriers to role effectiveness for nurse leaders include broad roles and functions, increased organizational complexity and large spans of control with time and financial constraints. Because fiscal pressures are expected to continue and the need for organizations to restructure in response is a constant reality, a sound evaluation of what changes in senior leadership roles produce the most positive outcomes is essential to guide future restructuring.

\section{References}

Aiken, L.H., S.P. Clarke and D.M. Sloane. 2002. "Hospital Staffing, Organization, and Quality of Care: Cross-National Findings". Nursing Outlook 50: 187-94.

Aiken, L.H. and P.A. Patrician. 2000. "Measuring Organizational Traits of Hospitals: The Revised Nursing Work Index. Nursing Research 49(3): 146-53.

Aiken, M. and J. Hage. 1966. "Organizational Alienation: A Comparative Analysis". American Sociological Review 31: 497-510.

Ashmos, D.P., J.W. Huonker and R.R. McDaniel Jr. 1998. “Participation as a Complicating Mechanism: The Effect of Clinical Professional and Middle Manager Participation on Hospital Performance." Health Care Management Review 23(4): 7-20. 
Banaszak-Holl, J., J. Alexander, N.M. Valentine, M.M. Piotrowski, J.G. Adams-Watson and J. Davis. 1999. "Decision-making Activity and Influence of Nurse Executives in Top Management Teams." Journal of Nursing Administration 29(4): 18-24.

Baumann, A., L. O’Brien-Pallas, M. Armstrong-Stassen, J. Blythe, R. Bourbonnais, S. Cameron, D. Irvine Doran, M. Kerr, L. McGillis Hall, M. Zina, M. Butt and L. Ryan. 2001. Commitment and Care: The Benefits of a Healthy Workplace for Nurses, Their Patients and the System. Ottawa: Canadian Health Services Research Foundation.

Broughton, H. 2001. Nursing Leadership: Unleashing the Power. Ottawa: Canadian Nurses Association.

Canadian Health Services Research Foundation 2006. Looking Forward, Working Together: Priorities for Nursing Leadership in Canada. Ottawa: Author.

Canadian Institute for Health Information. 2001. Supply and Distribution of Registered Nurses in Canada, 2000. Ottawa: Author.

Canadian Institute for Health Information. 2002. Supply and Distribution of Registered Nurses in Canada, 2001. Ottawa: Author.

Canadian Institute for Health Information. 2003. Workforce Trends of Registered Nurses in Canada, 2002. Ottawa: Author.

Canadian Institute for Health Information. 2004. Workforce Trends of Registered Nurses in Canada, 2003. Ottawa: Author.

Canadian Nursing Advisory Committee. 2002. Our Health, Our Future: Creating Quality Workplaces for Canadian Nurses. Ottawa: Advisory Committee on Health Human Resources.

Clifford, J.C. 1998. Restructuring: The Impact of Hospital Organization on Nursing Leadership. San Francisco, CA: Jossey-Bass Publishing.

Dewar, R.D., D.A. Whetton and D. Boje. 1980. "An Examination of the Reliability and Validity of the Aiken and Hage Scales of Centralization, Formalization, and Task Routineness. Administrative Science Quarterly 25: 120-28.

Doran, D., A.S. McCutcheon, M.G. Evans, K. MacMillan, L. McGillis Hall, D. Pringle, S. Smith and A. Valente. 2004. Impact of the Manager's Span of Control on Leadership and Performance. Ottawa: Canadian Health Services Research Foundation.

Eisenberger, R., J. Cummings, S. Armeli and P. Lynch. 1997. "Perceived Organizational Support, Discretionary Treatment, and Job Satisfaction". Journal of Applied Psychology 82(5): 812-20.

Eisenberger, R., P. Fasolo and V. Davis-LaMastro. 1990. "Perceived Organizational Support and Employee Diligence, Commitment, and Innovation." Journal of Applied Psychology 75(1): 51-99.

Eisenberger, R., R. Huntington, S. Hutchison and D. Sowa, D. 1986 "Perceived Organizational Support". Journal of Applied Psychology 71(3): 500-07.

Ferguson-Pare, M., G. Mitchell, K. Perkin and L. Stevenson. 2002. Academy of Canadian Executive Nurses Background Paper on Leadership. Toronto, ON: Academy of Canadian Executive Nurses.

Gelinas, L.S. and M.M. Manthey. 1997. "The Impact of Organizational Redesign on Nurse Executive Leadership. Journal of Nursing Administration 27(10): 35-42

Gittell, J.H. 2001. "Supervisory Span, Relational Coordination, and Flight Departure Performance: A Reassessment of Postbureaucracy Theory." Organization Science 12(4): 468-83.

Gresham, J.A.S. and H.N. Brown. 1997. "Supervision: How Satisfied Are Middle Nurse Managers? Nursing Management 28(1): 41-4.

Grinspun, D. 2000. "Taking Care of the Bottom Line: Shifting Paradigms in Hospital Management. In D.L. Gustafson, ed., Care and Consequences.
Halifax, NS: Fernwood Publishing.

Hage, J. and M. Aiken. 1967. "Relationship of Centralization to Other Structural Properties". Administrative Science Quarterly 12: 72-92.

Havens, D.S. 1998. "An Update on Nursing Involvement in Hospital Governance: 1990-1996.” Nursing Economics 16(1): 6-11.

Havens, D.S. 2001. "Comparing Nursing Infrastructure and Outcomes: ANCC Nonmagnet CNEs Report." Nursing Economics 19(6): 258-66.

Irvine, D.M. and M.G. Evans. 1995. "Job Satisfaction and Turnover among Nurses: Integrating Research Findings across Studies." Nursing Research 44(4): 246-53.

Kouzes, J.M. and B.Z. Posner.2000. Leadership Practices Inventory: Psychometric Properties. San Francisco, CA: Wiley.

Laschinger, H.K.S., J.E. Finegan, J. Shamian and P. Wilk.2001. "Impact of Structural and Psychological Empowerment on Job Strain in Nursing Work Settings: Expanding Kanter's Model". Journal of Nursing Administration, 31: 260-72.

Leatt, P., L. Lemieux-Charles and C. Aird, eds. 1994. Program Management and Beyond: Management Innovations in Ontario Hospitals. Ottawa: Canadian College of Health Service Executives.

Loke, J.C.F. 2001. "Leadership Behaviours: Effects on Job Satisfaction, Productivity and Organizational Commitment." Journal of Nursing Management 9(4): 191-204.

Mass, H, L. Brunke, S. Thorne and H. Parslow. 2006. "Preparing the Next Generation of Senior Nursing Leaders in Canada: Perceptions of Role Competencies and Barriers from the Perspectives of Inhabitants and Aspirants. Canadian Journal of Nursing Leadership 19(2): 75-91.

Michalski, J.H., E. Creighton and L. Jackson. 1999. "The Impact of Hospital Restructuring on Social Work Services: A Case Study of a Large, University-Affiliated Hospital in Canada. Social Work in Health Care 30(2): 1-27.

Miller, M.A. and L.D. Miller. 1997. "Effects of the Program-Management Model: A Case Study on Professional Rehabilitation Nursing. Nursing Administration Quarterly 21(2): 47-54.

Norrish, B.R. and T.G. Rundall. 2001. "Hospital Restructuring and the Work of Registered Nurses." The Milbank Quarterly 79(1): 55-79.

O'Brien-Pallas, L.L., G. Tomblin Murphy, H.K.S. Laschinger, S. White and B. Milburn. 2004. Survey of Employers: Health Care Organizations' Senior Nurse Managers. Ottawa: Nursing Sector Study Corporation.

Ontario Ministry of Health Report of the Nursing Task Force. 1999. Good Nursing, Good Health: An Investment for the 21st Century. Toronto: Queen's Printer for Ontario.

Patrick, A. And H. K. Laschinger. 2006. "The Effect of Structural Empowerment and Perceived Organizational Support on Middle Level Nurse Managers' Role Satisfaction." Journal of Nursing Management 14: $13-22$.

Pincus, J.D. 1986. "Communication: Key Contributor to Effectiveness - The Research. Journal of Nursing Administration 16(9): 19-25.

Prescott, P.A. and S.A. Bowen. 1987. Controlling Nursing Turnover. Nursing Management 18(6): 60, 62-6.

Putti, J.M., S. Aryee and J. Phua. 1990. "Communication Relationship Satisfaction and Organizational Commitment". Group \& Organization Studies 32(1): 44-52.

Quinn, R.P. and L.G. Shephard. 1974. The 1972-1973 Quality of Employment Survey. Ann Arbor: University of Michigan, Institute for Social Research.

Raudenbush, S., A. Bryk and R. Congdon. 2005. HLM for Windows, 
Hierarchical Linear and Nonlinear Modeling, Version 6.01. Lincolnwood, IL: Scientific Software International.

Relf, M. 1995. "Increasing Job Satisfaction and Motivation While Reducing Nursing Turnover through the Implementation of Shared Governance." Critical Care Nursing Quarterly 18(3): 7-13.

RNAO. 2006. Healthy Work Environments Best Practice Guidelines. Developing and Sustaining Nursing Leadership. Toronto, Ontario: Author.

Rose, M.D. and B.M. Reynolds. 1995. "How to Make Professional Practice Models Work." Critical Care Nursing Quarterly 18(3): 1-6.

Shortell, S.M., J.E. Zimmerman, D.M. Rousseau, R.R. Gillies, D.P. Draper and E.A. Draper. 1994."The Performance of Intensive Care Units: Does Good Management Make a Difference?" Medical Care 32(5):508-525.

Smith, D.L., H.E. Klopper, A. Paras and A. Au. 2006. "Structure in Health Agencies." In J. Hibberd and D. Smith, eds., Nursing Leadership and Management in Canada (3rd ed.). Toronto: Elsevier Canada.

SPSS Incorporated. 2005. SPSS for Windows Version 14.0. Chicago: SPSS, Inc.

Webb, S.S., S.A. Price and H. Coeling. 1996. "Valuing Authority/ Responsibility Relationships: The Essence of Professional Practice. Journal of Nursing Administration 26(2): 28-33.

\section{About the Authors}

Heather K. Spence Laschinger, RN, PhD, Distinguished University Professor, is the Associate Director of Nursing Research at the School of Nursing, University of Western Ontario, London, Ontario.

Carol A. Wong, RN, PhD(c), is Assistant Professor in the School of Nursing, University of Western Ontario.

Judith Ritchie, RN, PhD, is Professor and Associate Director of Nursing Research at McGill University Health Centre, Montreal, Quebec.

Danielle D'Amour, RN, PhD, is Professor and Director, Centre FERASI, University of Montreal, Montreal, Quebec.

Leslie Vincent, RN, MScA, is the Senior Vice-President of Patient Services and Chief Nursing Executive at Mount Sinai Hospital, Toronto, Ontario.

Piotr Wilk, PhD, is the Senior Scientist of Public Health Research, Education and Development Unit, Middlesex-London Health Unit, London, Ontario.

Marjorie Armstrong Stassen, PhD, is Professor Emerita at Odette School of Business, University of Windsor, Windsor, Ontario.

Sue Matthews, RN, DPH, is the Ontario Vice-President Operations and Chief of Practice for the Canada Victoria Order of Nurses.

Marcy Saxe-Braithwaite, RN, MScN, is the Vice-President of Programs and Chief Nursing Officer at the Providence Continuing Care Centre, Kingston, Ontario.

Doris Grinspun, $\mathrm{RN}, \mathrm{PhD}$ (c), O.Ont., is the Executive Director of the Registered Nurses' Association of Ontario, Toronto, Ontario.

Judith Shamian, RN, PhD, is the Chief Executive Officer of the Victorian Order of Nurses, Ottawa, Ontario.

Amy McCutcheon, $\mathrm{RN}, \mathrm{PhD}$, is the Chief Nursing Executive and Executive Lead of Professional Practice, Vancouver Coastal Health Authority, Vancouver, British Columbia.

Michael Kerr, PhD, is Associate Professor at the School of Nursing, University of Western Ontario, and is with the Institute of Work and Health, Toronto, Ontario.

Sandra Macdonald-Rencz, RN, MScN, is Executive Director, Office of Nursing Policy, Health Canada, Ottawa, Ontario.

Barbara Oke, RN, MScN, is Special Advisor, First Nations and Inuit Health Branch, Health Canada, Ottawa, Ontario.

Donna Denney, RN, MScN, is Provincial Nursing Officer, Nova Scotia Department of Health, Halifax, Nova Scotia.

Jerry White, PhD, is Professor at the Department of Sociology and Senior Advisor to the Provost, Office of the Provost and VicePresident (Academic), University of Western Ontario

Joan Almost, $\mathrm{RN}, \mathrm{PhD}(\mathrm{c})$, is a doctoral student in the Faculty of Nursing, University of Toronto, Toronto, Ontario and Project Director for this study.

\section{Acknowledgements:}

Funding for this project: Canadian Health Services Research Foundation/Canadian Institutes of Health Research, the Ontario Health Services Research Co-sponsorship Fund from Ontario Ministry of Health and Long-term Care, and Nursing Research Fund; London Health Sciences Centre, Vancouver Coastal Health Authority, Mount Sinai Hospital, Registered Nurses Association of Ontario, Office of Nursing Policy (Health Canada), Centre FERASI, Ministère de la Santé et des Services Sociaux du Québec; Canadian Institutes of Health Research, Knowledge Translation Branch, Nursing Leadership Network of Ontario.

\section{S Longwoods Review}

Longwoods Review is an integrated section of Healthcare Quarterly featuring peer-reviewed, applied research.

Editorial Advisory Board Philip Berman

Director, European Health Management Association, Dublin, Ireland

Michael Guerriere, MD, MBA Managing Partner, Courtyard Group Toronto, ON

Peggy Leatt, PhD

Professor and Chair, Department of Health Policy and Administration, Associate Dean for Academic Affairs, School of Public Health, University of North Carolina at Chapel Hill, Chapel Hill, NC
Cam Mustard, ScD

Professor, Department of Public Health Sciences, University of Toronto Faculty of Medicine, President/Scientific Director, Institute for Work \& Health, Toronto, ON Dorothy Pringle, PhD Professor and Dean Emeritus, Faculty of Nursing, University of Toronto, Toronto, ON

Enrique Ruelas, $\mathrm{PhD}$

Senior Undersecretary, Mexico Health, Mexico City, Mexico

Eugene Schneller, $\mathrm{PhD}$ Professor and Director. School of Health Administration \& Policy, Arizona State University, Tempe, AZ 


\section{A Profile of the Structure and Impact of Nursing Management in Canadian Hospitals}

Heather K. Spence Laschinger, Carol A. Wong, Judith Ritchie, Danielle D'Amour, Leslie Vincent, Piotr Wilk, Marjorie Armstrong Stassen, Sue Matthews, Marcy Saxe-Braithwaite, Doris Grinspun, Judith Shamian, Amy McCutcheon, Michael Kerr, Sandra Macdonald-Rencz, Barbara Oke, Donna Denney, Jerry White, and Joan Almost

\section{Appendix 1. Definition of roles}

\begin{tabular}{|c|c|}
\hline Role & Definition \\
\hline Senior nurse leader & $\begin{array}{l}\text { The nurse who holds the most senior nursing leadership } \\
\text { position in an organization with direct responsibility for nursing. }\end{array}$ \\
\hline Middle manager & $\begin{array}{l}\text { Nurses or non-nurses in positions with line responsibility for } \\
\text { nursing and acute care patient areas, including outpatient or } \\
\text { ambulatory care areas in addition to in-patient care areas. } \\
\text { There is at least one level of management below their level and } \\
\text { one level above. }\end{array}$ \\
\hline First-line manager & $\begin{array}{l}\text { Nurses or non-nurses in positions with line responsibility for } \\
\text { nursing and acute care patient units/wards with staff nurses } \\
\text { reporting directly to them. There is no level of management } \\
\text { below them; however, they may have charge nurses, } \\
\text { supervisors or team leaders who report directly to them. }\end{array}$ \\
\hline Professional practice leaders & $\begin{array}{l}\text { Nurses in staff positions who are responsible for nursing within } \\
\text { the organization. This category does not include clinical nurse } \\
\text { specialists, nurse practitioners or nurse educators. }\end{array}$ \\
\hline Chief executive officer & $\begin{array}{l}\text { The individual who holds the title of president or chief executive } \\
\text { officer in the entire hospital or regional health authority. }\end{array}$ \\
\hline
\end{tabular}

\section{Appendix 2. Comparison of response rates}

\begin{tabular}{|l|c|c|c|c|c|c|}
\hline \multirow{2}{*}{} & \multicolumn{2}{|c|}{ Total } & \multicolumn{2}{c|}{ AHC } & \multicolumn{2}{c|}{ CH } \\
\cline { 2 - 7 } & N & $\%$ & $\mathbf{n}$ & $\%$ & $\mathbf{n}$ & $\%$ \\
\hline SNL & 63 & 95.5 & 30 & 100.0 & 33 & 91.7 \\
\hline MM & 231 & 60.2 & 148 & 57.8 & 83 & 64.8 \\
\hline FLM & 788 & 53.9 & 515 & 50.1 & 273 & 63.2 \\
\hline PPL & 30 & 75.0 & 21 & 87.5 & 9 & 56.3 \\
\hline CEO & 52 & 81.3 & 22 & 75.9 & 30 & 83.3 \\
\hline
\end{tabular}


Appendix 3. Measures of study variables

\begin{tabular}{|c|c|c|c|c|}
\hline Key Concept and Variables & Source & Instrument & $\begin{array}{l}\text { No. of } \\
\text { Items }\end{array}$ & Psychometrics \\
\hline $\begin{array}{l}\text { Organizational characteristics } \\
\text { General structure/management model }\end{array}$ & $\begin{array}{l}\text { SNL } \\
\text { MM } \\
\text { FLM }\end{array}$ & $\begin{array}{l}\text { Nurse Executive Questionnaire (adapted } \\
\text { from Havens 2001; Clifford 1998) }\end{array}$ & 43 & $\begin{array}{l}\text { New instrument, preliminary face and } \\
\text { content validity }\end{array}$ \\
\hline $\begin{array}{l}\text { Structural leadership characteristics } \\
\text { Leader roles/responsibilities/span of } \\
\text { control }\end{array}$ & $\begin{array}{l}\text { SNL } \\
\\
\text { MM } \\
\text { FLM }\end{array}$ & $\begin{array}{l}\text { Organization of Nursing Characteristics; } \\
\text { Nursing Involvement in Organizational } \\
\text { Governance; Span of Control (adapted } \\
\text { from Havens 2001; Clifford 1998) } \\
\text { Program/Portfolio Characteristics; View } \\
\text { of SNL's Role in Nursing Involvement in } \\
\text { Organizational Governance (adapted from } \\
\text { Havens 2001; Clifford 1998) }\end{array}$ & 64 & $\begin{array}{l}\text { New instrument, preliminary face and } \\
\text { content validity } \\
\text { New instrument, preliminary face and } \\
\text { content validity }\end{array}$ \\
\hline Decisional involvement & $\begin{array}{l}\text { SNL } \\
\text { CEO } \\
\text { MM } \\
\text { FLM }\end{array}$ & $\begin{array}{l}\text { Participation in Strategic Decision- } \\
\text { Making Scale (Banaszak-Holl et al. 1999) } \\
\text { Revised Participation in Strategic } \\
\text { Decision-Making Scale (Banaszak-Holl et } \\
\text { al. 1999) } \\
\text { Index of Centralization - Hierarchy of } \\
\text { Authority Subscale (Hage and Aiken } \\
\text { 1967) }\end{array}$ & 32 & $\begin{array}{l}\text { Cronbach alpha }=.74-.81 \\
\text { (Banaszak-Hall et al. 1999) } \\
\text { Original instrument Cronbach alpha = } \\
.74-.81 \text { (Banaszak-Hall et al. 1999) } \\
\text { Revised version: preliminary face and } \\
\text { content validity; Cronbach alpha = } \\
.82-.91 \text { (Ashmos et al 1998); }\end{array}$ \\
\hline $\begin{array}{l}\text { Individual characteristics } \\
\text { Leadership style }\end{array}$ & $\begin{array}{l}\text { SNL } \\
\text { MM } \\
\text { FLM }\end{array}$ & $\begin{array}{l}\text { Leadership Practices Inventory (Kouzes } \\
\text { and Posner 2000) }\end{array}$ & 30 & $\begin{array}{l}\text { Cronbach alpha: five subscales range } \\
\text { from } .75 \text { to } .93 \text { (Kouzes and Posner 2000) }\end{array}$ \\
\hline $\begin{array}{l}\text { Integrative mechanisms } \\
\text { Communication and coordination } \\
\text { mechanisms }\end{array}$ & $\begin{array}{l}\text { SNL } \\
\text { MM } \\
\text { FLM }\end{array}$ & $\begin{array}{l}\text { Communication and Coordination } \\
\text { Questionnaire (Shortell et al. 1994) } \\
\text { Communication Satisfaction Subscale } \\
\text { (Putti et al. 1990) }\end{array}$ & $\begin{array}{l}8 \\
7\end{array}$ & $\begin{array}{l}\text { Cronbach alpha: communication = .64 and } \\
\text { coordination = .75 (Shortell et al. 1994) } \\
\text { Cronbach alpha: } .90 \text { (Putti et al. 1990) }\end{array}$ \\
\hline $\begin{array}{l}\text { Outcomes } \\
\text { Perceived organizational support }\end{array}$ & $\begin{array}{l}\text { SNL } \\
\text { MM } \\
\text { FLM }\end{array}$ & $\begin{array}{l}\text { Organizational Support Scale } \\
\text { (Eisenberger et al. 1986) }\end{array}$ & 8 & $\begin{array}{l}\text { Cronbach alpha: .74-.95 (Eisenberger et } \\
\text { al. 1997) }\end{array}$ \\
\hline Influence on decisions & $\begin{array}{l}\text { SNL } \\
\text { MMM } \\
\text { FLM }\end{array}$ & $\begin{array}{l}\text { Index of Centralization - Participation } \\
\text { in Decision-Making Subscale (Hage and } \\
\text { Aiken 1967) }\end{array}$ & 4 & Cronbach alpha: .86; (Dewar et al, 1980) \\
\hline & $\begin{array}{l}\text { SNL } \\
\text { MM } \\
\text { FLM }\end{array}$ & $\begin{array}{l}\text { Work Alienation Scale (Aiken and Hage } \\
\text { 1966) }\end{array}$ & 6 & $\begin{array}{l}\text { Cronbach alpha: .85 (Patrick \& Laschinger } \\
\text { 2006) }\end{array}$ \\
\hline Support for professional practıce & $\begin{array}{l}\text { SNL } \\
\text { MM } \\
\text { FLM }\end{array}$ & $\begin{array}{l}\text { Nursing Work Index - Revised } \\
\text { (Organizational Support Subscale) (Aiken } \\
\text { and Patrician 2000) }\end{array}$ & 13 & $\begin{array}{l}\text { Cronbach alpha: .84; content, criterion } \\
\text { and construct validity established (Aiken } \\
\text { and Patrician 2000) }\end{array}$ \\
\hline Empowerment & $\begin{array}{l}\text { SNL } \\
\text { MM } \\
\text { FLM }\end{array}$ & $\begin{array}{l}\text { Conditions of Work Effectiveness - II } \\
\text { (Laschinger et al. 2001) }\end{array}$ & 19 & $\begin{array}{l}\text { Cronbach alpha: .79-. } 82 \text { (Laschinger et } \\
\text { al. 2001) }\end{array}$ \\
\hline Job satisfaction & $\begin{array}{l}\text { SNL } \\
\text { MMM } \\
\text { FLM }\end{array}$ & $\begin{array}{l}\text { Global Job Satisfaction Survey (Quinn } \\
\text { and Shephand 1974) }\end{array}$ & 6 & $\begin{array}{l}\text { Cronbach alpha: . } 85 \text { (Eisenberger, et al, } \\
\text { 1997) }\end{array}$ \\
\hline
\end{tabular}




\begin{tabular}{|l|l|l|l|l|}
\hline Key Concept and Variables & Source & Instrument & $\begin{array}{l}\text { No. of } \\
\text { Items }\end{array}$ & Psychometrics \\
\hline $\begin{array}{l}\text { Quality of care } \\
\text { Job Security } \\
\text { Intent to Leave }\end{array}$ & SNL & Nurse-assessed quality of care & 13 & Construct validity (Aiken et al., 2002) \\
\hline & FLM & & 1 & \\
\hline
\end{tabular}

FLM = first-line manager; $C E 0$ = chief executive officer; $M M=$ middle manager; $S N L=$ senior nurse leader.

Appendix 4. Significant mean differences in study variables by SNL role configuration

\begin{tabular}{|c|c|c|c|c|c|}
\hline Variable & SNL Authority & Mean & Score Range & $t$ & $p$ Value \\
\hline & \multicolumn{5}{|c|}{ Senior Nurse Leader } \\
\hline Perceived organizational support & $\begin{array}{l}\text { Staff } \\
\text { Line }\end{array}$ & $\begin{array}{l}4.51 \\
5.11\end{array}$ & $1-6$ & -2.06 & .04 \\
\hline SNL status & $\begin{array}{l}\text { Staff } \\
\text { Line }\end{array}$ & $\begin{array}{l}0.91 \\
1.90\end{array}$ & $0-2$ & -7.45 & .00 \\
\hline Quality of senior management decisions & $\begin{array}{l}\text { Staff } \\
\text { Line }\end{array}$ & $\begin{array}{l}3.47 \\
3.87\end{array}$ & $1-5$ & -2.11 & .04 \\
\hline SNL decision-making influence & $\begin{array}{l}\text { Staff } \\
\text { Line }\end{array}$ & $\begin{array}{l}3.58 \\
4.37\end{array}$ & $1-5$ & -3.28 & .01 \\
\hline \multirow[t]{2}{*}{$\begin{array}{l}\text { SNL extent of involvement in senior } \\
\text { management decisions }\end{array}$} & $\begin{array}{l}\text { Staff } \\
\text { Line }\end{array}$ & $\begin{array}{l}2.92 \\
3.70\end{array}$ & $1-5$ & -4.31 & .00 \\
\hline & \multicolumn{5}{|c|}{ Middle Manager } \\
\hline Perceived organizational support & $\begin{array}{l}\text { Staff } \\
\text { Line }\end{array}$ & $\begin{array}{l}4.46 \\
4.09\end{array}$ & $1-6$ & 2.01 & .05 \\
\hline SNL status & $\begin{array}{l}\text { Staff } \\
\text { Line }\end{array}$ & $\begin{array}{l}0.71 \\
0.92\end{array}$ & $0-2$ & -3.81 & .00 \\
\hline $\begin{array}{l}\text { SNL extent of involvement in senior } \\
\text { management decisions }\end{array}$ & $\begin{array}{l}\text { Staff } \\
\text { Line }\end{array}$ & $\begin{array}{l}2.46 \\
3.10\end{array}$ & $1-5$ & -4.56 & .00 \\
\hline Total empowerment & $\begin{array}{l}\text { Staff } \\
\text { Line }\end{array}$ & $\begin{array}{l}22.74 \\
21.46\end{array}$ & $6-30$ & 2.69 & .01 \\
\hline \multirow[t]{2}{*}{ Decision latitude } & $\begin{array}{l}\text { Staff } \\
\text { Line }\end{array}$ & $\begin{array}{l}4.07 \\
3.77\end{array}$ & $1-5$ & 2.44 & .02 \\
\hline & \multicolumn{5}{|c|}{ First Line Manager } \\
\hline Support for professional practice & $\begin{array}{l}\text { Staff } \\
\text { Line }\end{array}$ & $\begin{array}{l}2.97 \\
3.06\end{array}$ & $1-4$ & -2.05 & .04 \\
\hline SNL status & $\begin{array}{l}\text { Staff } \\
\text { Line }\end{array}$ & $\begin{array}{l}0.86 \\
0.97\end{array}$ & $0-2$ & -4.60 & .00 \\
\hline $\begin{array}{l}\text { SNL extent of involvement in senior } \\
\text { management decisions }\end{array}$ & $\begin{array}{l}\text { Staff } \\
\text { Line }\end{array}$ & $\begin{array}{l}2.81 \\
3.18\end{array}$ & $1-5$ & -6.21 & .00 \\
\hline Decision latitude & $\begin{array}{l}\text { Staff } \\
\text { Line }\end{array}$ & $\begin{array}{l}3.85 \\
3.66\end{array}$ & $1-5$ & 2.78 & .01 \\
\hline
\end{tabular}

$\mathrm{FLM}=$ first-line manager; $\mathrm{MM}=$ middle manager; $\mathrm{SNL}$ = senior nurse leader. 
Appendix 5. Significant correlations among SNL reports of SNL status, SNL decision influence, quality of senior management decisions and selected variables*

\begin{tabular}{|c|c|c|c|}
\hline & SNL Status & $\begin{array}{c}\text { SNL Decision } \\
\text { Influence }\end{array}$ & Quality of Decisions \\
\hline $\begin{array}{l}\text { Structural variables } \\
\text { Number of direct reports } \\
\text { Perceived organizational support } \\
\text { Quality of senior management decisions }\end{array}$ & $\begin{array}{l}.279 \\
.366 \\
.414\end{array}$ & $\begin{array}{c}.267 \\
.332 \\
-\end{array}$ & $\begin{array}{l}- \\
.420 \\
-\end{array}$ \\
\hline $\begin{array}{l}\text { Work-life variables } \\
\text { Support for professional practice } \\
\text { Total empowerment } \\
\text { Role satisfaction } \\
\text { Job satisfaction } \\
\text { SNL decision influence } \\
\text { Influencing human resources and policy decisions } \\
\text { Communication satisfaction }\end{array}$ & $\begin{array}{c}.337 \\
- \\
.286 \\
- \\
.367 \\
.315 \\
-\end{array}$ & $\begin{array}{c}- \\
.324 \\
- \\
- \\
- \\
.367 \\
-\end{array}$ & $\begin{array}{c}.598 \\
.474 \\
.282 \\
.501 \\
- \\
- \\
.325\end{array}$ \\
\hline $\begin{array}{l}\text { Quality of care } \\
\text { Change in quality of care }\end{array}$ & - & .240 & .322 \\
\hline
\end{tabular}

${ }^{*} p \leq .05$ (one-tailed).

Appendix 6. Significant correlations among span of control and selected variables by management level*

\begin{tabular}{|l|c|c|c|}
\hline \multirow{2}{*}{} & \multicolumn{3}{c|}{ Number of Direct Reports } \\
\cline { 2 - 4 } & SNL & MM & FLM \\
\hline Structural variables & - & -.179 & - \\
\hline SNL leadership style & .267 & - & - \\
\hline SNL's decision-making influence & .279 & - & - \\
\hline SNL status & - & -.162 & - \\
\hline Perceived organizational support & - & .146 & - \\
\hline Work-life variables & - & -.141 & .152 \\
\hline Intent to leave & - & - & -143 \\
\hline Decision latitude & - & - & - \\
\hline Influencing human resources and policy decisions & -105 \\
\hline Quality of care & -222 & - & - \\
\hline Change in quality of care & - & - & - \\
\hline Patients can manage at discharge & & - & - \\
\hline
\end{tabular}

$\mathrm{FLM}=$ first-line manager; $\mathrm{MM}=$ middle manager; $\mathrm{SNL}=$ senior nurse leader .

${ }^{*} p \leq .05$ (one-tailed). 
Appendix 7. Significant correlations among SNL leadership style and selected variables by management level*

\begin{tabular}{|c|c|c|}
\hline & \multicolumn{2}{|c|}{ SNL Leadership Style } \\
\hline & MM & FLM \\
\hline \multicolumn{3}{|l|}{ Structural variables } \\
\hline Self-rated leadership style & .415 & .397 \\
\hline Perceived organizational support & .467 & .505 \\
\hline Communication satisfaction & .470 & .296 \\
\hline \multicolumn{3}{|l|}{ Work-life variables } \\
\hline Total empowerment & .408 & .448 \\
\hline Support for professional practice & .194 & .245 \\
\hline Role satisfaction & .326 & .254 \\
\hline Job satisfaction & .235 & .280 \\
\hline Intent to leave & -.156 & -.079 \\
\hline Decision latitude & .266 & .235 \\
\hline Influencing human resources and policy decisions & .125 & .151 \\
\hline \multicolumn{3}{|l|}{ Quality of care } \\
\hline Change in quality of care & .179 & - \\
\hline Patients can manage at discharge & .150 & .128 \\
\hline
\end{tabular}

$\mathrm{FLM}=$ first-line manager; $\mathrm{MM}=$ middle manager; $\mathrm{SNL}=$ senior nurse leader.

${ }^{*} p \leq .05$ (one-tailed). 
Appendix 8. Significant Correlations Among Job Satisfaction and Selected Variables by Management Level

\begin{tabular}{|c|c|c|c|}
\hline & \multicolumn{3}{|c|}{ Job Satisfaction } \\
\hline & SNL & MM & FLM \\
\hline \multicolumn{4}{|l|}{ Structural Variables: } \\
\hline SNL Leadership style & $\mathrm{N} / \mathrm{A}$ & .235 & .280 \\
\hline POS & .608 & .542 & .555 \\
\hline Quality of senior mgt. decisions & .501 & $\mathrm{~N} / \mathrm{A}$ & $\mathrm{N} / \mathrm{A}$ \\
\hline Communication satisfaction & .577 & .343 & .336 \\
\hline \multicolumn{4}{|l|}{ Work-life Variables: } \\
\hline Total Empowerment & .597 & .576 & .554 \\
\hline Support for Professional Practice & .454 & .345 & .330 \\
\hline Role Satisfaction & .415 & .614 & .559 \\
\hline Intent to leave & -.435 & -.215 & -.271 \\
\hline Decision latitude & $\mathrm{N} / \mathrm{A}$ & .448 & .340 \\
\hline Influencing HR \& policy decisions & - & .262 & .184 \\
\hline \multicolumn{4}{|l|}{ Quality of Care: } \\
\hline Rating of Quality of Care & $\mathrm{N} / \mathrm{A}$ & .150 & .238 \\
\hline Change in Quality of Care & .232 & .231 & .216 \\
\hline Patients can manage at discharge & .323 & .303 & .195 \\
\hline
\end{tabular}

FLM = first-line manager; $\mathrm{MM}=$ middle manager; $\mathrm{SNL}=$ senior nurse leader.

${ }^{*} p \leq .05$ (one-tailed) 